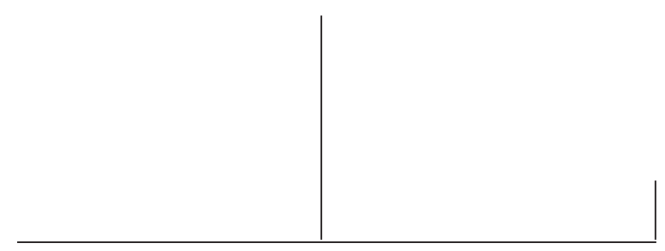

Rev. Latinoam. Psicopat. Fund., VII, 4, 7-31

\title{
Heráclito de Éfeso, filósofo do Lógos
}

\author{
Zeferino Rocha
}

$O$ artigo tem como objetivo mostrar o papel essencial do Lógos na filosofia de Heráclito de Éfeso e é dividido em três partes. Na primeira, o autor apresenta Heráclito como um pensador originário, cognominado de "o obscuro". A segunda parte faz algumas considerações sobre a etimologia da palavra Lógos, ressaltando o seu sentido originário, à luz do comentário de Heidegger aos Fragmentos 50 e 16 de Heráclito sobre o Lógos e a Alétheia, e focaliza a importância do sentido originário do Lógos para pensar o phynai da Physis, como o entendiam os primeiros filósofos gregos. A terceira parte mostra como Heráclito de Éfeso, com a doutrina do Lógos, redimensionou a visão da psyché humana que dominava a Grécia Arcaica.

Palavras-chave: Heráclito de Éfeso, Lógos e Lógos da psyché 


\section{Introdução}

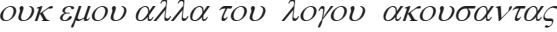

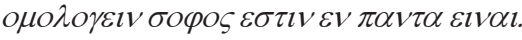

(Escutando não a mim,

mas ao Lógos, é sábio entrar em acordo para dizer a mesma coisa: tudo é um.)

Heráclito de Eféso (Frag. 50)

O Lógos tem um lugar de destaque na filosofia antiga, principalmente entre os filósofos chamados "pré-socráticos". Mas, quem são esses filósofos? Embora a designação de "pré-socráticos" tenha sido consagrada pela tradição filosófica, ela nada revela do que verdadeiramente foram esses primeiros pensadores da filosofia grega. Eles não foram apenas os antecessores de Sócrates, mas foram verdadeiros e profundos "pensadores originários", que se consagraram à tarefa de decifrar o enigma da origem e do vir-a-ser da Natureza. ${ }^{1}$

Após seu apogeu na filosofia da Grécia Clássica, o Lógos ocupou o centro da filosofia helenística, particularmente no estoicismo antigo, médio e tardio. Depois, em um novo contexto cultural, ele teve um lugar de realce na teologia cristã, tanto na Idade Patrística, por causa do encontro do cristianismo primitivo com a paidéia grega (Cf. Jaeger, 1961), quanto na Idade Média, devido à grande

1. Ver a este respeito o que escreve Emmanuel Carneiro Leão na interessante "Introdução" feita para a tradução dos textos de Parmênides, Anaximandro e Heráclito publicada pela Editora Vozes. Cf. Emmanuel Carneiro Leão e Sérgio Wrublewski. Pensadores originários: Anaximandro, Parmênides, Heráclito (1993). 


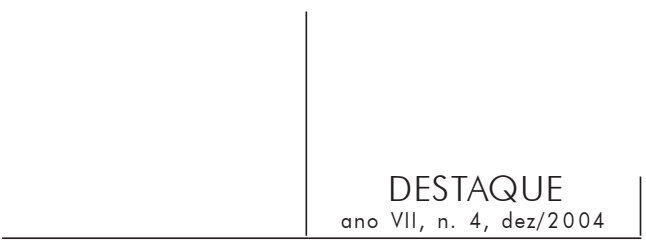

influência que, através de Platão, Plotino e Aristóteles, a cultura grega exerceu sobre a teologia medieval. Mais tarde, no projeto epistemológico da Modernidade, o Lógos foi substituído pela Razão Científica, e, finalmente, graças ao trabalho de Nietzsche (1973, p. 108-116) e, sobretudo, de Heidegger (1973a, Heráclito, frag. 50), ele foi resgatado no seu sentido originário, e vem ocupando, em virtude da interpretação que lhe deu Heidegger, um lugar privilegiado na filosofia da contemporaneidade.

Não sendo possível percorrer esta longa trajetória nos limites do presente ensaio, limitar-me-ei a resumir o que de mais sugestivo Heráclito de Éfeso escreveu sobre o Lógos nos fragmentos de sua doutrina filosófica, que até nós chegaram, deixando os outros dois marcos da trajetória para eventuais trabalhos, que, espero, poder escrever depois.

\section{Objetivo e roteiro}

O meu propósito no presente ensaio é mostrar o papel essencial do Lógos na filosofia de Heráclito de Éfeso. Para isso, vou dividi-lo em quatro partes: na primeira apresentarei Heráclito como um "pensador originário" que os seus contemporâneos cognominaram de "o obscuro" (Skoteinós); na segunda parte, farei algumas considerações sobre a etimologia da palavra lógos e, valendo-me do célebre comentário de Heidegger aos Fragmentos de Heráclito sobre o Lógos $e$ sobre a Alétheia, tentarei resgatar o sentido originário do lógos heraclitiano e mostrar sua importância para pensar o phynai da Physis, do modo como o entendiam os primeiros filósofos da Grécia Antiga; na terceira parte mostrarei como Heráclito de Éfeso, mediante a doutrina do Lógos, redimensionou a visão da psyché humana, que era dominante na Grécia Arcaica e finalmente, na quarta e última parte, articularemos o problema do Lógos com o da Divindade, perguntando se convém, ou não, atribuir ao Lógos de Heráclito o nome de Zeus.

Primeira parte

\section{Heráclito de Éfeso, um Pensador originário e obscuro}

Heráclito entrou no cenário da pesquisa filosófica, quando a filosofia grega, ainda em seus primórdios, tentava explicar a arché das coisas, a harmonia do

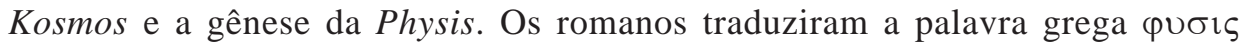




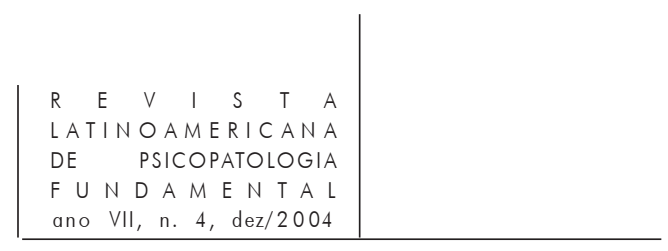

por natura (natureza), e, na língua portuguesa, o termo Physis é também traduzido por Física.

Física, Natureza, Ciência da Natureza, todas essas palavras tentam dizer a mesma coisa, mas nenhuma traduz, com exatidão, o que os primeiros filósofos gregos, aqueles que são chamados de "pensadores originários", entendiam por Physis. Para eles, a Physis tinha uma aura "divina", pois era a fonte originária, a arché de todas as coisas que constituíam o Universo. Na convergência divergente de sua unidade e na divergência convergente da diversidade de suas partes, a totalidade dos seres formava a harmonia cósmica, "a harmonia mais

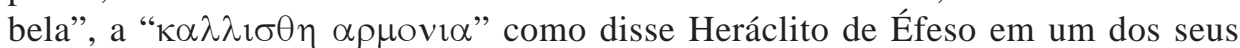
mais belos fragmentos. ${ }^{2}$

Esta unidade polivalente transparece, claramente, na etimologia latina da palavra Universus, que se poderia desdobrar assim: Universus $=$ omnia versus Unum, vale dizer, todas as coisas (omnia) estão voltadas para (versus) o Uno (Unum). Pois bem, de todas essas coisas, os primeiros filósofos gregos tentavam descobrir a origem $(\alpha \rho \chi \eta)$ e o processo de seu vir-a-ser ( $\varphi \cup v \alpha \imath)$. Portanto, o "pensamento originário", que deu origem ao filosofar na Grécia Antiga, foi inteiramente consagrado ao estudo do $\varphi v v \propto \iota$ (vir-a-ser) da $\varphi v \sigma ı \varsigma$ (Natureza).

Heidegger, porém, observa que esses pensadores originários "pensaram a

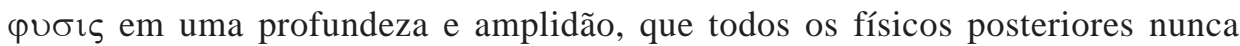
mais conseguiram alcançar (Cf. Heidegger, 1957, p. 138-9). Nem os posteriores, nem aqueles que os sucederam no estudo da Natureza.

Por "Natureza", a filosofia clássica entendia o princípio do movimento de todas as coisas, princípio este pelo qual essas coisas eram o que eram. Daí porque, em Aristóteles, natureza é sinônimo de forma, de substância e de essência (Cf. Aristóteles, Physica. II.1, 192b). No livro da Metafísica, ele define a Natureza como "a substância das coisas que têm o princípio do movimento em si próprias" (Cf. Aristóteles, Metaphysica. V. 4, 1015 a 13).

Heidegger, no entanto, opina que esse modo de conceber a Natureza não traduz o que os filósofos originários entendiam por Physis. Esta palavra era para eles fundamental e, literalmente, significava: "surgir no sentido de provir do que se acha escondido e velado". É o que pode ser observado, por exemplo, no desabrochar da rosa e no surgir da semente escondida no silêncio da terra. A visão do nascer do sol também exemplifica a essência do "surgimento" e o que

2. Heráclito de Éfeso, Fragmento n. 8: "O contrário em tensão é convergente e da divergência dos contrários, a mais bela harmonia”. Trad. de Carneiro Leão e Sérgio Wrublewski (1993), p. 61. Hermann Diels: "Das widereinander Strebende zusammengehend; aus dem auseinander Gehenden die schönste Fügung” (1957), p. 24. 


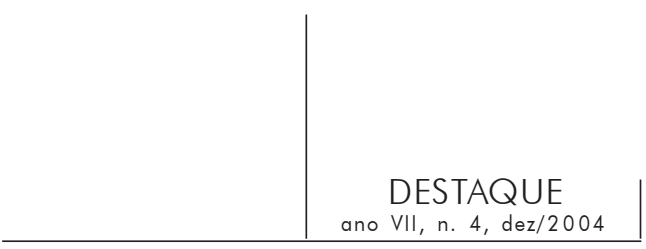

define a Physis como "um mostrar-se a partir de si e de dentro de si". Dito de outro modo: "a Physis é o ser mesmo em virtude do qual o ente se torna e permanece observável" (Heidegger, 1987, p. 45).

Ou seja, os pensadores originários consagraram-se ao estudo do emergir ou desvelar-se dos entes, que acontece como manifestações do Ser, a partir de seu velamento mais profundo. Pois, para eles, existe uma inter-relação muito significativa entre o esconder-se e o manifestar-se, os quais se atualizam no emergir das coisas ou no processo de seu desvelamento. É a unidade ambivalente desse velar-se e desvelar-se que revela a essência da Physis (Cf. Heidegger, 1973b, Heráclito, frag. 16, p. 135).

\section{Heráclito, o "obscuro"}

No contexto deste filosofar originário sobre a Physis, Heráclito de Éfeso deu ao Lógos um lugar de destaque, embora não se tenha dado a tarefa de revelar sua natureza. Digo isto porque o pensamento do filósofo de Éfeso habitou sempre a região do enigma, na qual tudo o que se manifesta, ao mesmo tempo se esconde, e tudo o que se esconde, simultaneamente se manifesta. Não por acaso, ele foi designado, ainda pelos seus contemporâneos, com o cognome de "o obscuro" (Ho Skoteinós). Mas qual o sentido desta obscuridade?

Referindo-se ao estilo heraclitiano, Heidegger opina que, em vez de ser denominado de "obscuro", Heráclito poderia e deveria ter sido chamado de "o claro", pois o que ele escreve no seu estilo enigmático, "clarifica e faz brilhar a linguagem do pensar" (ibid., p. 130). Esta claridade, porém, é uma claridade sui generis, pois tem o fascínio e o enigma dos relâmpagos. De um modo fugaz e efêmero, os relâmpagos, com seus repetidos clarões, iluminam a escuridão da noite, mas não conseguem transformá-la na claridade do dia.

Por este motivo, Heidegger comparou os pensamentos de Heráclito aos clarões dos relâmpagos em noite de tempestade. E a tempestade, que aqui está em questão, é uma tempestade sui generis, porque é a própria "tempestade do ser", ou seja, a tempestade da qual os filósofos, em geral, tentam fugir em nome de uma falsa tranqüilidade, a qual se dissimula sob a "apatia da angústia diante do pensar" e, sobretudo, do "a se-pensar" (Heidegger, 1973a, Heráclito, frag. 50, p. 129).

Talvez fosse interessante lembrar que é esta mesma "apatia da angústia", ou seja, o medo de assumi-la, que leva o homem a fazer a experiência da existência inautêntica em seu situar-se no mundo. Vamos, portanto, à luz desses clarões, refletir um pouco sobre o que o filósofo de Éfeso ensina sobre o Lógos. 


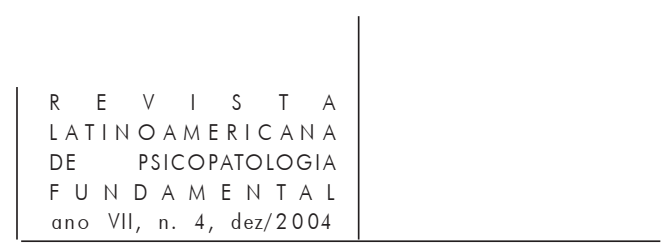

SEgunda PARTE

Da etimologia da palavra ao sentido originário do lógos e seu papel no PHYNAI DA PHYSIS

\section{A etimologia da palavra Lógos}

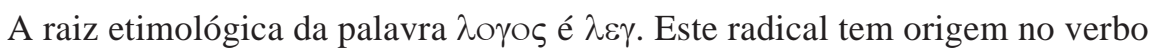
grego $\lambda \varepsilon \gamma \omega(\lambda \varepsilon \gamma \varepsilon i \eta)$. E no latim lego (legere). Pode-se resumir, em três grandes grupos, as principais significações e os diversos sentidos do verbo grego légein:

1) Na forma transitiva: deitar, colocar na cama; na forma reflexiva: deitar-se, ficar inativo;

2) juntar, pousar, recolher, escolher, reunir, contar, enumerar, narrar;

3) dizer, falar, declarar, anunciar, significar, nomear, designar, ordenar e exortar (Cf. Rocci, 1949). ${ }^{3}$

No belo livro que escreveu sobre Heráclito e ao qual deu o sugestivo título: Heráclito ou o homem entre as coisas e as palavras, Clémence Ramnoux (1959) aborda a questão do sentido do Lógos e questiona se, para Heráclito, o Lógos não designaria "la Chose même", vale dizer, a própria coisa, na medida em que esta se dá a conhecer, através da linguagem (p. 316-7).

Para ela, a palavra francesa leçon (lição), talvez não fosse uma má tradução para o lógos heraclitiano, porquanto, ao menos em francês, o vocábulo lição evoca a tarefa que o aluno deve aprender de cor, ou seja, o ensinamento do mestre e a interpretação que ele fazia dos textos obscuros. Mas, acrescenta ela, é preciso reconhecer que a palavra "lição" não poderia ser "um bom sujeito para o verbo ser", como o é a palavra lógos no seu sentido singular e original. E a grande helenista termina perguntando: a melhor solução, para o problema da tradução da palavra lógos, não seria adotar, em francês, o termo lógos, deixando-lhe a amplidão e a abertura de sentido, bem como sua aura de mistério? (ibid., p. 318).

Como quer que seja, Clémence Ramnoux observa que, embora Heráclito tenha distinguido um lógos divino (no singular) dos lógoi (no plural) dos mortais, seria precipitado concluir, que, já, na sua doutrina, podemos encontrar uma hipóstase da palavra Lógos, como vai acontecer depois, tanto na filosofia helenista

3. Veja-se também o Dicionário Grego-Português - Português-Grego de Isidro Pereira (s/d). Na língua latina, destacam-se entre as principais significações do verbo legere: ajuntar, reunir, recolher, colher, escolher, fazer escolha de, eleger, tocar de leve, ler, fazer leitura, explicar. Cf. F.R. dos Santos Saraiva. Novíssimo Dicionário Latino-Português, 1993. 


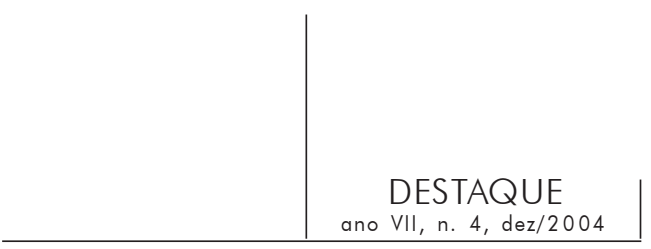

dos estóicos, quanto, sobretudo, na teologia do cristianismo primitivo e medieval. Isto, porém, não significa que o Lógos de Heráclito não possua um sentido mais arcaico e originário.

Heidegger adverte que não é fácil saber o que pensavam os pensadores originários sobre o Lógos. Quanto mais distantes de nós eles se encontram, mais difícil de se determinar se torna o que, para eles, constituía o "a se-pensar". Ademais a essência do Lógos é obscura e o segredo desta obscuridade não está na falta de conceitos adequados, mas nela mesma. É verdade que os lógicos (e para os antigos a Lógica, enquanto ciência do pensamento, derivava do Lógos) sempre articularam o lógos com a palavra, o discurso e a linguagem.

Mas, para eles, o Lógos não se esgotava na dimensão lingüística. Havia nele algo de impensado e era precisamente esta dimensão impensada do Lógos que se oferecia na obscuridade como um "a se-pensar" (Heidegger, Heráclito, 1973a, p. 252 e segs.). Quanto a Heráclito, Heidegger opina que talvez seja o que ele pensa sobre o Logos, o que há de mais obscuro no seu pensamento já tido desde a antigüidade como obscuro.

\section{O sentido originário do Lógos de Heráclito}

Pois bem, é exatamente para resgatar o sentido arcaico e originário do Lógos heraclitiano, que Heidegger empenhou-se em fazer um comentário minucioso do Fragmento 50. Hoje, não é mais possível discutir a questão do Lógos, nem o sentido que ela tem na filosofia de Heráclito, sem levar em consideração este comentário de Heidegger. Valendo-nos dele e do que o mesmo Heidegger diz ainda comentando o Fragmento 16 sobre a Alétheia, bem como o que acrescentou no seu livro sobre Heráclito, vamos tentar mostrar a importância que tem o Lógos, no seu sentido originário, para nos ajudar a pensar o enigma do $\varphi v v \alpha \imath$ da $\varphi v \sigma \imath \varsigma$.

O objetivo de Heidegger, ao comentar o Fragmento 50 de Heráclito de Éfeso sobre o Lógos, é resgatar o sentido mais arcaico e originário desta palavra. Eis o fragmento na tradução do próprio Heidegger:

Se não ouvirem simplesmente a mim, mas se tiverem auscultado

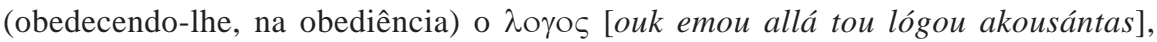

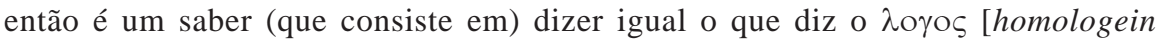
sophón estin]: tudo é um [Hèn Pánta]. ${ }^{4}$

4. Heráclito de Éfeso. Frag. 50. Clémence Ramnoux traduz: "En écoutant non pas moi, mais le Logos, il est sage de tomber d'accord pour confesser la même chose: tout est un." Cf. 


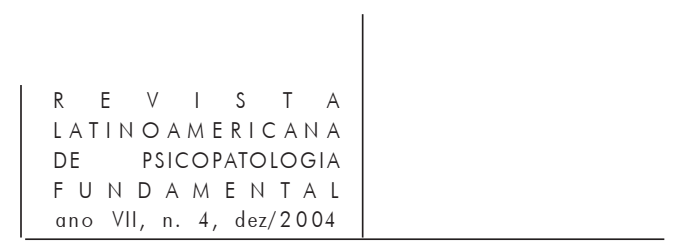

A sentença é enigmática e, certamente, também o era para os contemporâneos de Heráclito. Pois bem, de alguma forma, é para decifrar o seu enigma, que Heidegger sente necessidade de refletir sobre a etimologia do verbo légein e, dela, tirar o sentido originário da palavra Lógos. Somente assim, diz ele, será possível reencontrar o seu sentido originário, que, no decorrer da História da Filosofia, conheceu várias interpretações, entre as quais prevaleceram aquelas que, nele, viram a Ratio, na sua função de Lei do mundo e Lei do pensamento, vale dizer, a Razão que dita as normas do fazer e do dizer.

\section{Do légein-recolher ao légein-dizer}

Logo de início, Heidegger lembra que, inegavelmente, o verbo légein significa dizer e falar, mas, em um sentido mais arcaico, ele significa também "deitar, estender-diante-de-si, colher, recolher e apresentar a si e aos outros o que se recolhe". Necessário se faz, então, descobrir como se processa esta passagem do sentido mais arcaico do légein-colher e recolher para o légein-dizer e falar. E é precisamente quando tenta compreender esta passagem, que Heidegger constrói sua interpretação do sentido originário da palavra Lógos.

A sugestiva imagem da colheita, na dinâmica poética de seu acontecer, é um pousar ou colocar-as-coisas-diante-de-si; depois vem o juntar e o recolher; depois o abrigar o que se recolheu em algum lugar. $\mathrm{O}$ recolher exige concentração. Mas esta concentração já está inserida no pousar, pois o-que-se-estende-diante é muito importante. Assim se procede quando se colhe e recolhe a lavoura, as uvas na videira, a madeira na floresta. Colher não é apenas apanhar o que está no chão, é apanhar com cuidado, suspender, resguardar. Apanha-se, a partir do que se deve resguardar.

O mesmo se poderia dizer da coleta. Coletar não é apenas ajuntar. Aqui também coleta-se a partir do que se deve resguardar e a "coletagem" do que se deve resguardar surge da própria coleta e nela se esconde, isto é, se coleta (Cf. Heidegger, Heráclito, 1973a, p. 280). E Heidegger conclui: "É a partir do $\lambda \varepsilon \gamma \varepsilon \imath v$ pensado originariamente como colheita e coleta, que se oferece um caminho para a compreensão do significado corrente da 'colheita' como leitura e apreensão da escrita da palavra escrita como palavra e discurso" (ibid., p. 281).

Clémence, Ramnoux, 1957, p. 220. Hermann Diels: "Haben sie nicht mich, sondern den Sinn vernommen, so ist es weise, dem Sinne gemäâ zu sagen, alles sei eins". Cf. Diels, Hermann, 1957, p. 26. Carneiro Leão, Emmanuel e Wrublewski, S., 1993, p. 71: "Auscultando não a mim, mas o Logos, é sábio concordar que tudo é um." 


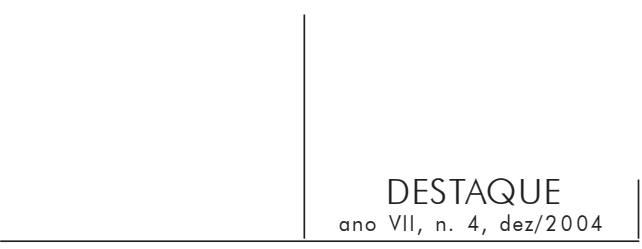

Todavia, a passagem do légein-colher para o légein-dizer e falar não se faz por meio de uma modificação de natureza semântica, mas mediante um processo especial de des-velamento, e este des-velamento se faz pela linguagem. Já desde aí aparece que, para Heidegger, ser e linguagem se interpenetram mutuamente.

O légein-colher e recolher é também um velar e um ocultar. Tudo o que se recolhe, oculta-se. Por isso, o colher e o recolher só vão encontrar seu sentido originário em um processo de “des-velamento". E é aí que se esconde, para

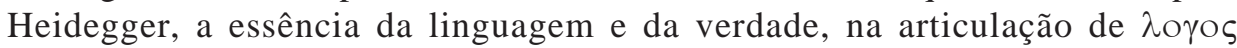
$\alpha \lambda \eta \theta \varepsilon \imath \alpha$ e $\Phi v \sigma \iota \varsigma$.

O légein-dizer desvela e revela o que foi velado. Para traduzi-lo com as próprias palavras de Heidegger: "a desocultação do oculto, no desvelado, é a presença daquilo que se presenta". Presentar-se, na leitura heideggeriana, é o velar que se ilumina. Mas há um permanecer velado na proximidade daquilo que se presenta. Portanto, o desvelar-se não apenas não elimina o velar-se, mas dele necessita para ser assim como é, vale dizer, um des-velamento. Pois bem, é na unidade do velar-se e desvelar-se que se esconde a essência da Physis. Nesta unidade, Heidegger vê ainda o ser dos entes, a essência da verdade e a essência da linguagem.

Nada ilustra melhor a unidade essencial do velar-se e do desvelar-se e o seu papel no phynai da Physis, do que aquilo que Heráclito sentencia no Fragmento 123. Nele pode-se ler:

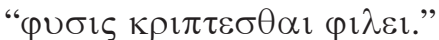

O que significa: "A Natureza ama esconder-se". E como o que define a Physis é o manifestar-se do Ser nos entes que emergem, como des-velamento de si mesmo, quando Heráclito diz que o emergir da Physis ama esconder-se, ele está colocando o emergir e o velar-se na mais próxima vizinhança.

Heidegger chama a atenção para o philei (ama) que, no Fragmento de Heráclito, une a Physis (emergir) e o kriptesthai (velar-se). Porque ama o esconder-se, a Physis gosta de estar junto dele. Para Heidegger, a Physis, em questão, não é a essência ou "quididade" (quidditas) das coisas, mas o "emergir", o "surgir" que acontece em sua manifestação como desvelamento de si mesmo. No velar-se, escondem-se as possibilidades do emergir (Heidegger, 1973b, Heráclito, frag. 16, p. 129-42). 


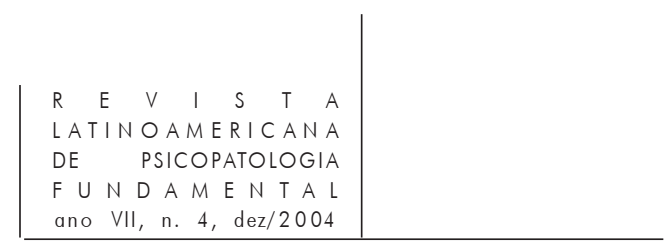

\section{Dizer e escutar}

O sentido originário do Lógos revela também a essência do dizer e do escutar. A essência do dizer não se esgota na expressão verbal, ou na sua significação, como pensava a filosofia tradicional da linguagem. É no légeinpousar-que-recolhe que, para Heidegger, se esconde o que há de mais originário no falar da linguagem humana. Pois ela se produz a partir do des-velamento das coisas que se presentam na presença. O Lógos leva aquilo-que-se-estende-diantede-si, ou seja, a totalidade de todas as coisas que se reúnem no Uno, a mostrarse a partir de sua presença. Ou, ainda, a um automostrar-se na clareira, como desdobramento do Ser.

Se esta é a essência do dizer, o que seria, então, a essência do escutar? Se o dizer não se esgota na expressão sonora dos vocábulos, o escutar também não se restringe à captação auditiva dessas sonoridades. Escutar é um recolherse concentrado na palavra que nos é dirigida. É um ouvir recolhido. Só escutamos verdadeiramente, quando "somos todo ouvidos". Para escutar é preciso fazer parte do que se escuta, ou seja, sentir no mesmo sentido (homologein).

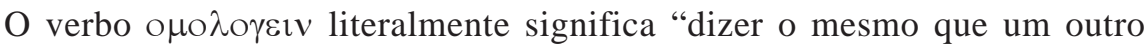
diz", ou seja, confirmar o que um outro diz. O que se diz em se mostrando, acrescenta Heidegger, exige confirmação. Por isso, no escutar, o légein (dizer) desdobra-se em um homologein (estar de acordo com o mesmo dizer). Para que as coisas presentes brilhem e apareçam na presença, o légein-dizer desdobra-se em um homologein da escuta. Heidegger interpreta o homologein como uma escuta obediente ao lógos, que consiste em dizer o que o lógos diz. Escutar na obediência é tornar-se obediente ao dizer que nos vem ao encontro, dizer este a que já pertencemos. Um escutar assim, como já sabemos, é um ir além do som das palavras. É sintonizar com aquele que fala.

Talvez se pudesse acrescentar: só se ouve bem o que se ama. Para ouvir o Lógos, é preciso amá-lo. Ou, para dizê-lo com as palavras de Heráclito, para escutar o Lógos é preciso primeiro pertencer-lhe, fazer parte dele. O verdadeiro escutar desdobra o légein (dizer) em um homologein (estar de acordo com o que é dito).

E quando isto acontece, quando se escuta o Lógos, acontece também o que é sábio [sophós]. Encontra-se a sabedoria. E, na interpretação de Heidegger, ser sábio é ser "bem disposto" pelo destino, vale dizer, é aceitar o que o Uno, que tudo reúne, dispõe, pois é ele quem determina a morada da essência dos entes. Por isso, quando se é sábio se diz: Um é tudo (Hèn Panta)". 


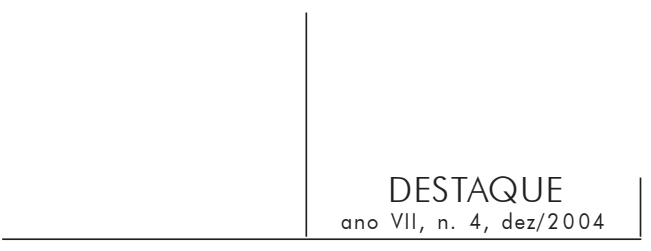

Hèn Pánta (Um Tudo)

Mas o que quer dizer Heráclito com a expressão Hèn Pánta (Um Tudo)? Será, porventura, aquilo que o Lógos anuncia? Ou seja, o sentido de tudo o que existe? Se assim fosse, o Lógos seria a Razão que dirige o grande concerto da Orquestra Cósmica, assegurando a harmonia invisível dos contrários. ${ }^{5}$ Ora, para Heidegger, esta interpretação, embora correta, não é a originária, pois no sentido originário a fórmula heraclitiana "Hèn Pánta" (Um Tudo) significa o desdobramento do Ser no Lógos.

Ho Hèn (o Uno) une enquanto reúne, ou melhor, une enquanto o légein recolhe. O Uno reúne em si o tudo que unifica. Assim sendo, Hèn Pánta diz o que o Lógos é. O Lógos recolhe o-que-está-estendido-diante-em-conjunto, ou seja, a presença das coisas que se presentam e nomeia o que reúne na presença. Heidegger observa que a presença das coisas que se presentam é aquilo que os gregos chamavam: tò einai ton ónton, e os latinos: o esse entium, ou seja, o ser dos entes.

Enquanto "Ev" (um) o Lógos abraça a amplitude de tudo o que recolhe. Tudo é um. Heidegger observa que, nesse "Tudo é um”, algo de essencial é nomeado, mas sua explicação não é fácil. Talvez, como ele próprio sugere: "no ser e como ser o uno une tudo o que é". Ou, dito com outras palavras, no "Um" que reúne todos os entes, cada ente recebe o traço fundamental de seu ser (Cf. Heidegger, Heráclito, 1973a, p. 275).

Se o Lógos é o nome do ser dos entes, não é de estranhar que ele tenha se tornado a palavra-diretriz da filosofia de Heráclito. Ele estaria na base da verdadeira Ontologia, daquilo que Heidegger chamou depois de Ontologia Fundamental. Assim, no começo do pensamento ocidental, a essência da linguagem brilhou à luz do ser. Este clarão, no entanto, foi efêmero como o dos relâmpagos.

De fato, Heidegger reconhece que os gregos e o próprio Heráclito, embora "habitando na linguagem" (lembremos que, para ele, "a linguagem é a morada do Ser" ["Die Sprache ist das Haus des Seins"] (Cf. Heidegger, 1957, p. 24-5), não pensaram o ser como linguagem, nem a essência da linguagem a partir da essência do Ser. Os clarões que, em Heráclito, uniam Ser e Linguagem, logo se apagaram na noite do esquecimento. E teve o mesmo destino que a questão do Ser e da Verdade do Ser.

5. Cf. Heráclito de Éfeso. Frag. 8: "O contrário em tensão é convergente; da divergência dos contrários, a mais bela harmonia". E o Frag. 54: "A harmonia invisível é mais forte do que a visível". 


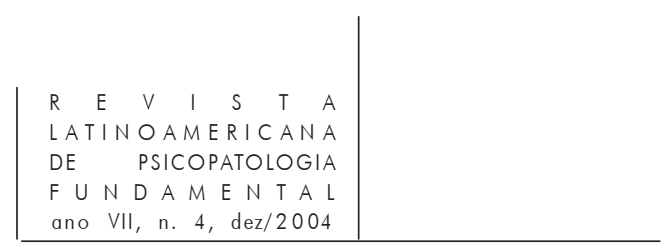

\section{Lógos e Alétheia}

Portanto, na interpretação de Heidegger, pode-se dizer que "Ho Lógos légei". E isto significa: o Lógos colhe e coleta todos os seres (pánta ta ónta), ou seja, tudo aquilo que se recolhe na presença e se presenta no des-velamento. E isso une Lógos e Alétheia, pois o légein-que-pousa-e-recolhe e vela, desvela enquanto légein que nomeia. Coloca-se, desse modo, a questão da Verdade do Ser.

O Hèn Pánta, a totalidade das coisas que se reúnem e se manifestam no Lógos, tem, nesse Uno, mais do que a harmonia dos contrários. Tem, diz Heidegger, o seu destino, vale dizer, o destino que determina, para tudo que existe, o lugar que lhe é devido, a essência que lhe convém.

\section{Terceira Parte}

\section{O LógOS DA PSYCHÉ HUMANA}

Depois de ter refletido, à luz do comentário de Heidegger aos Fragmentos 50 e 16 sobre o papel do Lógos no vir-a-ser da Physis, vejamos, agora, de que modo Heráclito, com sua doutrina do Lógos, redimensionou a visão da psyché humana na Grécia Arcaica.

\section{A psyché na tradição homérica}

No tempo de Homero, os gregos ainda não dispunham de uma doutrina filosófica teoricamente sistematizada sobre o homem. Corpo e alma não tinham ainda encontrado uma teorização adequada. O pensamento épico voltava-se, de preferência, para a descrição dos grandes feitos, através dos quais era cantada a aventura da vida. De modo solene e grandioso, ele enaltecia o espetáculo da vida, em uma modalidade literária, que se poderia dizer: uma estética da objetividade. Quando Homero fala do corpo, o que lhe interessa é a realidade concreta deste corpo, na diversidade de suas configurações e de seus limites (Snell, 1975, p. 13-29).

Da mesma forma, na tradição homérica, a alma não tinha ainda nenhuma consistência ôntica. Ela dava vida ao corpo, mas quando o corpo morria, ela o abandonava, para vagar nas regiões escuras do Hades, como uma mera sombra, um "eidolon", ou seja, uma simples imagem do morto. 


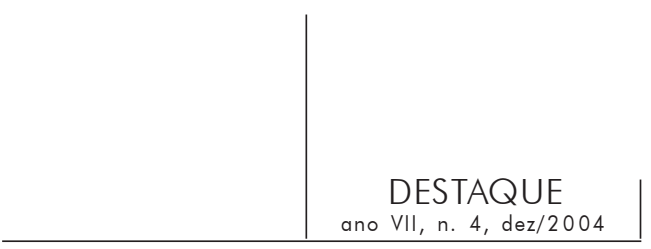

O homem homérico não tinha ainda consciência de seu mundo interior, nem do papel estruturante e dinamizador da psyché no que se refere à motivação, deliberação e escolha das razões de seu agir. Os estímulos, que o animavam para as grandes ações doadoras de sentido à vida, eram considerados dons dos deuses.

Eram os deuses, como diz Píndaro na sétima ode das Nemênias, que vindo em socorro dos mortais, faziam, neles, crescer um belo lógos (Píndaro. Nemênias, apud Ramnoux, 1959, p. 116-8) e um belo thymós. O thymós, para o grego arcaico, era considerado o órgão da afetividade. Ele era a fonte, em que se nutriam o ardor combativo e o coração valente dos guerreiros em campo de batalha. Considerar o lógos e o thymós como dons dos deuses, era completamente natural, pois o homem homérico vivia na vizinhança do Divino. Este pertencia à ordem natural do mundo.

Somente quem recebia dos deuses um belo lógos e um belo thymós conseguia escapar da noite do esquecimento depois da morte. Os demais seres mortais eram marcados pelo estigma da finitude e da mortalidade. Píndaro descreveu, de modo muito triste, esta trágica condição da finitude humana, em um verso que se tornou célebre:

"Efêmeros! O que, portanto, cada um de nós é?

E o que não é?

O homem é o sonho de uma sombra”. ${ }^{6}$

\section{O Lógos da psyché}

Pois bem, foi através de sua doutrina do lógos, e, em particular, mediante o conceito do lógos da psyché, que Heráclito redimensionou a visão da alma humana na Grécia arcaica. ${ }^{7}$ Com Heráclito, a alma já assume uma função especial tanto como princípio de vida, quanto como princípio de pensamento e de afetividade. Heráclito justapõe inteligência e afetividade no fragmento 104.

Segundo Jean Frère (1981, p. 92) que fez um excelente estudo daquilo que os filósofos gregos disseram sobre o desejo, em Heráclito existem duas palavras para designar o pensamento: a palavra nous e phren. A primeira indica o pensamento discursivo logicamente ordenado, a segunda um pensamento intuitivo, um pensamento do coração que é comum a todos os homens, pois é através dele que eles pertencem ao Lógos e se tornam capazes de escutá-lo.

6. Pindaro, Pythicos, 8. 5, v.1. Tradução de Clémence Ramnoux (1957) p.101.

7. Retomo aqui nas suas linhas essenciais o que sobre o lógos da psyché escrevi no meu artigo "O desejo na Grécia Arcaica" (1999). 


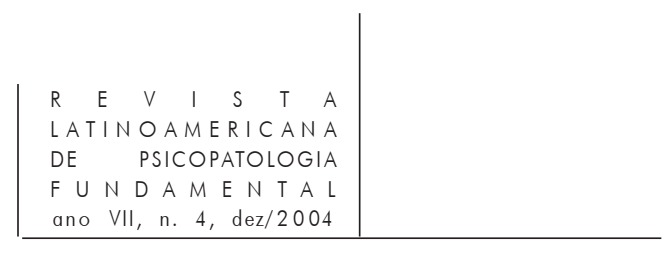

Dir-se-ia que ressaltando o aspecto phren do pensamento, Heráclito se coloca entre aqueles para os quais só se conhece bem o que se ama. É enquanto phren que a alma ama e deseja. É a psyché, enquanto vous e phren, que vai abrir os caminhos da alma, aqueles que o fragmento 45, indiscutivelmente, um dos mais belos que Heráclito nos deixou, diz que são intransponíveis:

"Caminhando não encontrarás os limites da alma, mesmo se percorreres todas as estradas, pois é muito profundo o lógos que ela possui."

(Heráclito de Éfeso, frag. 45)

Mas o que se deve entender por esse lógos da psyché, que Heráclito afirma ser tão profundo? Os especialistas ensinam que são vários os seus possíveis

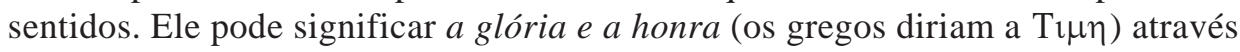
das quais o homem escapa da noite do esquecimento e sobressai entre os demais. O lógos da psyché pode significar as infindáveis estradas que a psyché enquanto phren abre para serem exploradas. Mas pode também significar o lógos na sua dimensão originária da qual participa a alma na medida em que é envolvida pelo Lógos - o Hèn Pánta - no mistério de suas possibilidades infindas.

O próprio Heráclito, no fragmento 39, refere-se ao lógos de Bias, nascido 20 em Priene e filho de Teutames e diz que ele era maior do que o dos outros homens seus companheiros (ibid., frag. 39). Tudo indica que este lógos do homem é o que dele se diz, ou, mais exatamente, o que os poetas e os aedos contam e cantam a seu respeito.

Daí a força e o poder que tinha a palavra dos poetas. Eles tanto podiam promover a honra e a glória do herói, tirando-o da noite do esquecimento e imortalizando-o pela lembrança, como podiam também criar-lhe uma falsa glória. A palavra poética assegurava aos grandes feitos dos heróis a sua persistência na lembrança dos homens.

Mas o herói podia também ser frustrado de sua glória, seja por falta de um canto adequado, seja pela astúcia dos "fabricantes de mentiras". ${ }^{8}$ Os gregos também conheceram esses profanadores da palavra, que dela se utilizavam para semear a mentira. Deles, porém, se encarregaria a Justiça, a qual, para Píndaro, não era outra senão o próprio Tempo.

Os "fabricantes de mentiras" podiam também se exceder nos elogios e pecar assim pela desmedida. Ora, para o grego arcaico, nada tão prejudicial quanto a desmedida. O próprio Heráclito parece ter isto sempre presente, quando, no

8. Heráclito de Éfeso. Frag. 28: "O homem digno de fé sabe e conserva o que se deve acreditar. Quanto aos fabricantes e testemunhas de mentiras a Justiça os apanhará". 


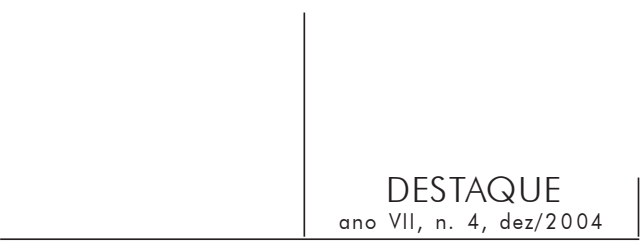

fragmento 43, adverte: "a hybris, ou seja, o desejo desmedido deve ser apagado mais do que os incêndios".

Além desta interpretação do lógos da psyché, pode-se também dizer que, na medida em que possui um lógos muito profundo, a alma adquire uma dimensão de interioridade e de profundidade, que a tradição homérica nem de longe poderia ter imaginado. Naquela tradição, enalteciam-se, no homem, os membros exteriores (o corpo ágil e musculoso), pois, mediante eles, eram valorizados o guerreiro na guerra, o soldado nos combates e os atletas nos jogos. Também sobressaía o órgão da fala, porque através dela o cidadão se destacava nas assembléias.

Ressaltando a dimensão profunda da interioridade da alma, Heráclito valoriza o homem, que tendo um belo lógos, sabe, com um "saber prudente" que ensina a sabedoria ${ }^{10}$ - qual o verdadeiro sentido daquilo que se diz e daquilo que faz e age. Para Heráclito, o verdadeiro valor do homem que fazia grandes ações ou que proferia grandes discursos estava no conhecer o sentido daquilo que fazia e daquilo que dizia. Sem isto nem um nem outro, para ele, tinha valor. ${ }^{11}$

Ésquilo ajuda-nos a compreender o sentido deste lógos muito profundo da psyché humana, quando o interpreta como aquele que vem do fundo do coração:

"Eu vou pronunciar, porquanto tu o mandas,

o lógos que vem do fundo do coração."

(apud Ramnoux, 1959, p. 298)

Portanto, o que torna profundo o lógos da psyché é que ele não se restringe ao conhecimento das muitas coisas que existem na superfície e se descobrem com a inteligência, o que ele conhece, conhece com o coração, conhece com um "saber prudente" (sophronein).

Poder-se-ia perguntar se o lógos da psyché, que vem do fundo do coração, é aquele mesmo que Píndaro, na sétima das Nemênias louva dizendo: "A honra vai para aqueles, nos quais, o deus, vindo em socorro dos mortais, faz crescer um belo lógos" (apud Ramnoux, 1959, p. 116). Ele é um lógos divino ou um lógos humano? A questão se põe, porque no Fragmento 115, Heráclito diz: “o lógos da alma é próprio e aumenta-se a si mesmo".

Assim sendo, parece que o lógos da alma é diferente do lógos divino, ou seja, aquele que, como vimos, é um dom dos deuses e que, segundo Píndaro, os deuses fazem crescer no coração dos homens. Estaria Heráclito iniciando aquele trabalho de racionalização do lógos, que depois foi feito por Demócrito e

9. Heráclito. Frag. 112: "Conhecer com um saber prudente ( $\sigma \omega \varphi \rho \circ v \varepsilon \imath v)$ é a maior virtude".

10. Heráclito de Éfeso: Frag. 40: "Muitos conhecimentos não ensinam a sabedoria".

11. Ver o que a este respeito escreve Clémence Ramnoux, 1959, p. 297-300. 


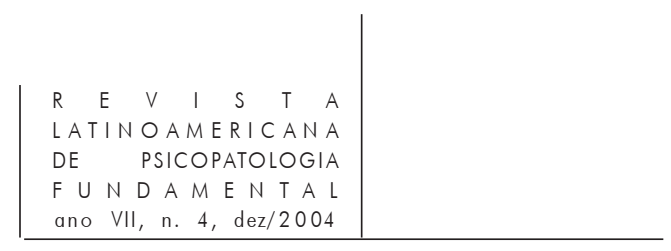

pelos sofistas em um movimento cultural que Henrique de Lima Vaz (1994) chamou de "modernidade grega"? Clémence Ramnoux (1959, p. 348) é de opinião que dificilmente se poderia fazer do lógos da psyché heraclitiano um equivalente da consciência de si do homem moderno.

Mesmo que não se possa ver no lógos da psyché um equivalente da consciência de si do homem moderno, não parece duvidoso que, para Heráclito, ele tem consistência própria e tem nele mesmo o segredo de seu crescimento. No contexto geral da doutrina de Heráclito, pode-se dizer que o que faz o logos da psyché crescer não são os muitos conhecimentos, pois "muitos conhecimentos não ensinam a sabedoria" (Heráclito de Éfeso, frag. 40). E como diz o fragmento 35: "para investigar muitas coisas, é necessário que sejam os homens amantes da sabedoria". Portanto, o que faz crescer a alma são os ensinamentos dos sábios.

Discutem os especialistas se a expressão "tão profundo é o lógos que ela possui" do fragmento 45, foi realmente escrita por Heráclito, ou se não foi acrescentada depois por Diógenes Laércio? Talvez. Dificilmente se poderia eliminar as dúvidas e estas se tornam cada vez maiores, quanto mais a ciência se especializa. Mas nem por isso pode-se deixar de reconhecer que ela exprime, de um modo muito feliz, uma nova manifestação do acontecer psíquico em um momento bem particular da História do pensamento grego. ${ }^{12}$ E Heráclito teve o merecimento de captá-la porque era daqueles que sabiam "escutar o Lógos".

\section{Quarta Parte}

\section{O LÓGOS E A DIVINDADE}

Nos fragmentos, Heráclito atribui ao Lógos outros nomes. Assim, por exemplo, no fragmento 64, o Lógos é chamado de kerainós, que significa: raio, relâmpago. Já vimos que é, sob os clarões efêmeros dos relâmpagos, que o raio, para dizê-lo com as palavras do próprio Heidegger, "libera o que brilha para a sua aparição". E esse brilho tem o fulgor dos relâmpagos, vale dizer, "o que ele clarifica, dura enquanto clarifica". Pois bem, na medida em que as coisas são desveladas, elas são conduzidas para seu destino, ou seja, para a morada de sua essência.

12. Permito-me remeter o leitor ao meu artigo "Psyché. O caminhos do acontecer psíquico na Grécia Antiga" (2001). 


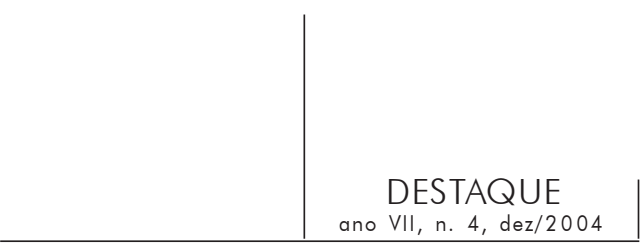

Heráclito exprime isto quando, no Fragmento 64, afirma que "o raio governa todas as coisas". O "raio" (Kerainós) pode ser considerado um outro nome do Lógos. Que o raio seja visto como divino, não é de estranhar, porquanto, para Heráclito, o fogo é a arché originária de todas as coisas. E no fragmento 30 lêse: "O cosmos, o mesmo para todos, nenhum dos deuses e nenhum dos homens o fez, mas sempre foi, é e será fogo sempre vivo, acendendo segundo a medida e segundo a medida se apagando".

Nas metamorfoses do fogo há uma presença imanente do Divino. Todavia, porque imanente a todos, o divino transcende cada ente. Dir-se-ia que ele é o "sendo" que todas as coisas "são" além de si mesmas. O Divino tudo governa. Ele "dirige tudo através de tudo", mas "é separado de tudo e de todos". ${ }^{13}$ Esta imanência que se transcende e esta transcendência que é imanente tornam muito ambíguo o sentido que o Divino tem para Heráclito. Imanente em todas as coisas, ele reúne em si todos os contrários. Por isso, ele "é noite, dia, inverno, verão, guerra, paz, saciedade, fome” (Heráclito de Éfeso, frag. 67; cf. Jeanière, 1959), vale dizer, a totalidade de todas as coisas. Mas, de tudo ele é separado (Heráclito de Éfeso, frag. 108).

Há ainda uma outra passagem, por sinal bastante enigmática, em que Heráclito ressalta esta ambigüidade do Um Tudo que está em tudo e que de tudo se separa. É quando, no fragmento 98, ele escreve: “as almas respiram segundo

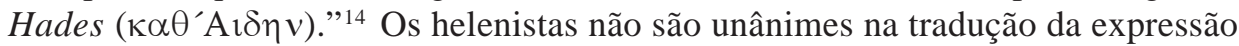
"kath'Aiden". Uns a entendem e traduzem como se Heráclito se referisse ao lugar do Hades, onde as almas se encontrariam depois da morte, não dispondo, porém, de outra forma de vida se não a olfativa. Outros, de modo que parece mais convincente, defendem que, na citada expressão, Heráclito quer ressaltar duas coisas que seriam atribuídas ao Lógos-Uno que tudo reúne: a venerabilidade e a invisibilidade.

Assim, Jean Frère no seu estudo sobre Os gregos e o desejo do ser interpreta o enigmático fragmento da seguinte maneira: quando Heráclito diz que as almas respiram segundo o Hades, ele está querendo dizer que elas se nutrem

13. Heráclito de Éfeso. Frag. 104: "Um, o saber: compreender que o pensamento, em qualquer tempo, dirige tudo através de tudo". Frag. 108: "De todos aqueles de quem escutei as palavras, nenhum consegue esclarecer que o sábio é algo separado de todos".

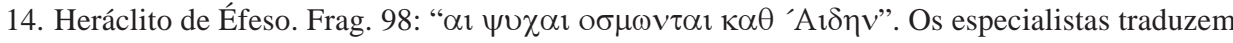
de modo bastante diferente este fragmento. Hermann Diels: "Die Seelen atmen Geruch ein im Hades", 1957, p. 29. Clémence Ramnoux: "Les âmes dans 1'Hadès perçoivent les senteurs", 1959, p. 126). Carneiro Leão e Sérgio Wrublewski: "Os alentos sentem odores segundo o invisível", 1993, p. 85. 


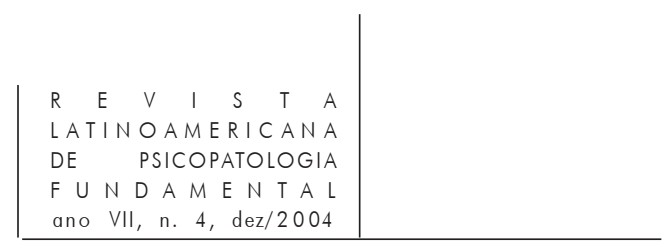

de $e$ aspiram ao invisível. "O fragmento não nos fala de um além, mas do aqui e do agora. Toda alma nutre-se do in-visível, aspira ao in-visível e respira o invisível". ${ }^{15}$

Poderia o Lógos ser também chamado de Zeus? Pode-se dizer que, para Heráclito, o Lógos era um outro nome daquele que os gregos cultuavam como seu deus supremo?

\section{O nome de Zeus}

No Fragmento 32, lê-se: "O Uno (Ho Hèn), o único sábio (tò sophòn mounon) não quer ser chamado (legésthai ouk ethélei) e quer (kai ethélei) com o nome de Zeus (Zenòs ónoma)" ${ }^{16}{ }^{16}$ Heidegger propõe que se traduza o verbo ethélo, não por querer, mas por "estar, a partir de si, preparado para". Para ele, o fragmento anuncia que o unicamente Uno - que tudo unifica (ho Hèn) e que tudo recolhe (ho Lógos) -, não está preparado para ser reunido sob o nome de Zeus. Se tal ocorresse, ele manifestar-se-ia "em um modo de aparecer que, talvez, sempre devesse permanecer apenas aparência". Assim, ele seria rebaixado a um nível de presença semelhante à presença das demais coisas que se presentam e manifestam.

Aos olhos de Heidegger, quando se leva em consideração a distinção entre o légein-pousar e o légein-dizer, descobre-se que o nome não exprime somente a significação da palavra, mas significa, originariamente, o que está recolhido, aguardando o apelo de se manifestar à luz do "raio" (Lógos) que governa todas as coisas.

Neste contexto, pode-se melhor compreender o sentido do nome de Zeus. Ele poderia ser visto como aquele que tudo recolhe na totalidade do Uno. Todavia, querer dar a este Uno, que tudo recolhe, um nome, mesmo que seja o nome de Zeus (o deus supremo dos gregos), como sempre fez a Metafísica tradicional, é rebaixá-lo ao nível de ser de uma coisa presente entre as demais coisas, pouco importando que esta coisa esteja acima de todas as outras.

15. "Le fragment ne nous parle pas de l'au-dela mais d'ici et du maintenant. Toute âme se nourrit de l'in-visible, aspire à l'in-visible, respire l'in-visible. Point question ici d'une poétique vision d'un au-delà aux senteurs de garrigues. Nous traduisons: 'Les âmes respirent par rapport à Hadès"”. Cf. Frère, 1981, p. 35.

16. Heráclito de Éfeso. Frag. 32. Tradução de Emmanuel Carneiro Leão e Sérgio Wrublewski. In Os pensasores originários, 1993, p. 67. Hermann Diels (1957) traduz o fragmento da seguinte maneira: "Eins, das allein Weise, will nicht und will doch mit dem Namen des Zeus benannt werden (p. 26). 


\section{DESTAQUE}

ano VII, n. 4, dez/2004

Daí a ênfase com a qual Heráclito afirma que o Uno (Hèn) que tudo unifica não está preparado, ou não aceita o nome de Zeus. É sabido que Heráclito desdenhava as representações antropomórficas do Divino e ridicularizava os rituais através dos quais a Divindade era cultuada, como se vê no fragmento 5: "É em vão que se purificam, aspergindo-se com sangue, como se alguém, que tivesse pisado na lama, quisesse lavar-se com lama; e fazem suas preces às imagens como se alguém pudesse falar com as paredes".

Ele também afirma, no fragmento 15 , que os rituais dionisíacos, com seus hinos fálicos, seriam a coisa mais vergonhosa, não fossem eles celebrados em homenagem a Dionísio. Ora, Dionísio e Hades, continua Heráclito, são o mesmo. Se levarmos em conta que a palavra $A \imath \delta \eta \varsigma$ remete tanto a $\alpha \_\delta o l \alpha$ (= as partes vergonhosas), quanto a $\alpha \_\delta \varepsilon \varsigma$ (= invisível), aqui também teríamos uma confirmação de que o verdadeiro sentido dos rituais fálicos celebrados em homenagem a Dionísio, só aparece quando vamos além das aparências. O seu verdadeiro sentido - aquele no qual aparece o que neles existe de venerável (aidoios) - permanece invisível (aidés). Os adeptos de Dionísio não descobrem o verdadeiro sentido dos rituais que eles celebram em homenagem ao seu deus.

Mas Heráclito afirma também que o Hèn, que é igualmente o Lógos, aceita e quer ser nomeado de Zeus. Enquanto "pousar que recolhe", ele não é percebido em si mesmo e não aceita o nome de Zeus. Mas enquanto "raio" que governa todas as coisas e Lógos que nomeia as coisas todas que se presentam na presença, ele aceita o nome de Zeus.

Como quer que seja, não é fácil estabelecer a relação entre o Lógos e o légein dos mortais. Como pode a fala dos mortais nomear o deus supremo, sem banalizar seu mistério? Talvez, diante do mistério, a melhor fala seja o silêncio. Heráclito enfatiza isto, quando lembra que só se pode "ouvir o Lógos", se o légein for desdobrado em um homologein, vale dizer, se o mortal que escuta consente no que diz o Lógos. Que isto seja também válido para o falar, é o que sugere, de modo admirável, o fragmento 19, quando sentencia: "Não sabendo auscultar, não sabem falar".

Neste contexto, Heidegger, então, questiona a fala dos teólogos e dos metafísicos quando representam o Lógos como o modo de ser mais fundamental e mais elevado do légein dos mortais. O Lógos não pode ser reduzido à medida do légein, nem mesmo à sua máxima potencialização. Ou, dito com outras palavras: para Heidegger, o sentido originário do Lógos heraclitiano só pode ser decifrado, na medida em que a questão do Lógos for relacionada com a questão da Verdade do Ser. É só, neste contexto, que se pode também perguntar se o Lógos é divino e se pode ser chamado pelo nome de Deus. 


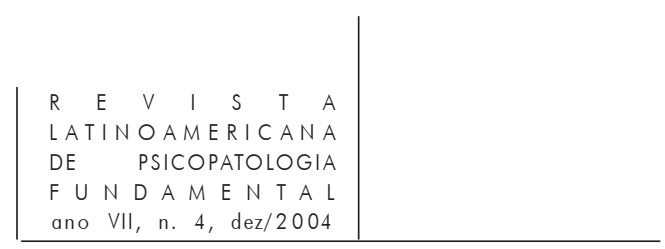

Heidegger e a divindade

Salvo melhor juízo, sou de opinião que Heidegger, na interpretação do Lógos de Heráclito, exprime o que ele próprio, como filósofo do Ser, pensa a respeito da Divindade. E quando fala da Divindade, ele certamente não se refere ao Deus dos filósofos, pois este, ele sempre desprezou, como algo infinitamente aquém daquilo que se poderia dizer a respeito de Deus.

Pode-se dizer que sobre a Divindade, Heidegger sempre guardou o mais profundo e respeitoso silêncio. De fato, não pode ser outra a posição do filósofo diante do enigma e do abismo sem fundo e inefável do mistério de Deus. Ao filósofo não compete falar sobre Deus, porque nenhuma palavra humana é capaz de traduzir o mistério de Deus.

E quando sobre ele falam os teólogos, estes incorrem no mesmo defeito em que caem os metafísicos, quando falam sobre o Ser. O aparato conceitual de que se serve a Teologia relega ao esquecimento o verdadeiro sentido daquilo que se quer interrogar sobre a Divindade. Dir-se-ia que, para Heidegger, falar sobre a Divindade não é fácil, porque, aqui também, o légein precisa ser desdobrado em um homologein.

Como já foi visto, Heráclito fala sobre a necessidade de primeiramente se pertencer ao Lógos, para, então, poder ouvir o que ele diz. E, sabendo escutar, aprender também a falar. Pois bem, Heidegger não me parece longe disto, quando escreve:

A falta de Deus e do Divino é uma ausência. Só que a ausência não é nada, mas ela é a presença - de que é preciso, primeiro, apropriar-se - da plenitude oculta do que foi e que é assim reunido: o divino nos gregos, nos profetas, na pregação de Jesus. Este Não-mais é nele mesmo um Não-ainda da vinda velada de seu ser inesgotável. ${ }^{17}$

Heidegger sempre se deixou motivar pelo desafio do mais arcaico e do mais originário. Assim, ele procedeu para resgatar o sentido originário não só do Lógos de Heráclito, mas da própria Questão do Ser e da Verdade do Ser. Não é de estranhar, portanto, que ele também tenha pensado que somente, neste contexto, se pudesse colocar a questão do nome de Deus. É o que nos assegura esta passagem do livro Über den Humanismus, na qual se lê:

17. Cf. Heidegger, M.,1954, p. 183. Os grifos são meus. Utilizo a citação feita por Maria do Carmo Tavares de Miranda no seu artigo "Martin Heidegger, filósofo do Ser", 1976. [O grifo é meu]. 


\section{DESTAQUE}

ano VII, n. 4, dez/2004

... o pensamento, que pensa a partir da questão que concerne à Verdade do Ser, questiona de um modo mais originário do que pode fazer a Metafísica [... das Denken, das aus der Frage nach der Wahrheit des Seins denkt, anfänglicher fragt, als die Metaphysik fragen kann.] Somente a partir da Verdade do Ser, podese pensar a essência do Sagrado [Erst aus der Wahrheit des Seins lässt sich das Wesen des Heiligen denken]. Somente a partir da essência do Sagrado, pode-se pensar a essência da Divindade [Erst aus dem Wesen des Heiligen ist das Wesen von Gottheit zu denken.] Somente à luz da essência da Divindade, pode-se pensar e dizer o que deve denominar a palavra "Deus" [Erst im Lichte des Wesen von Gottheit kann gedacht und gesagt werden, was da Wort "Gott" nennen soll'.] (Heidegger, 1959, p. 130-1)

Heidegger, porém, adverte que daí não se deve concluir que seu pensamento, centrado na questão da Verdade do Ser, seja um pensamento teísta. Para ele, a Ontologia fundamental nem é teísta nem ateísta. E isto, não por indiferentismo religioso, mas simplesmente porque o pensamento, que aponta para a Verdade do Ser, deve levar em consideração os limites que são fixados ao pensamento enquanto pensamento, e o são por aquilo mesmo que lhe é dado como o que se deve pensar, vale dizer, a Verdade do Ser. ${ }^{18}$

Como quer que seja, se Heidegger, enquanto filósofo, prefere guardar um respeitoso silêncio diante da questão da Divindade, o mesmo não se poderia dizer de Heráclito. Como todo homem da Grécia arcaica, Heráclito vivia em íntimo contato com o Divino. Basta lembrar o que sentencia o fragmento 119:

$$
\begin{aligned}
& \text { "O daimon, morada para o homem }
\end{aligned}
$$

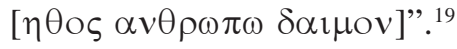

E se seguirmos o breve comentário que Heidegger faz a este fragmento no livro Über Humanismus, descobriremos que a palavra ethos, a qual, na concepção

18. "Com esta indicação, não poderia, de modo algum, o pensamento, que sinala a verdade do Ser, como o que se deve pensar, ter se decidido pelo teísmo. [Doch mit disem Hinweis möchte sich das Denken, das in die Wahrheit des Seins als das Zu-denkende vorweist, keineswegs für den Theismus entscheiden haben]. Tal pensamento não pode nem um pouco ser teísta ou ateísta [Theistisch kann es so wenig sein wie atheistisch]. Isto, porém, não em razão de uma atitude de indiferença, mas em atenção aos limites que são fixados ao pensamento enquanto pensamento, e o são por aquilo mesmo que lhe é dado como o que se deve pensar, vale dizer, a verdade do Ser. [Dies aber nicht auf Grund einer gleichgültigen Haltung, sondern aus der Achtung der Grenzen, die dem Denken als Denken gesetzt sind und zwar durch das, was sich ihm als Zu-denkende gibt, durch die Wahrheit des Seins]. Cf. Heidegger, M.,1957, p. 132-3.

19. Heráclito de Éfeso. Frag. 119 - Hermann Diels traduz o fragmento da seguinte maneira: "Seine Eigenart [ O seu caráter próprio] ist dem Mensch sein Dämon [é para o homem, o seu Daimon], d.h. sein Geschick [isto é, seu destino]. Emmanuel Carneiro e Sérgio Wrublewski: “ a morada do homem, o extraordinário". 


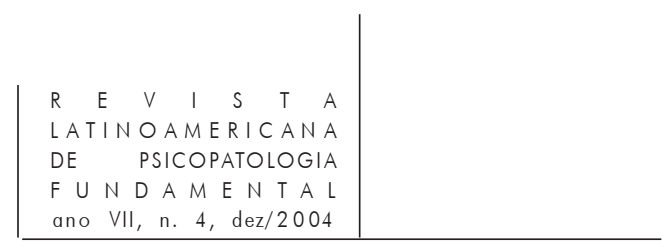

moderna, costuma-se traduzir por caráter ou particularidade, para os gregos antigos significava "morada", ou "o domínio aberto onde o homem habita" (Heidegger, 1957, p. 138-9).

E, para Heráclito, o $\delta \alpha \imath \mu \mathrm{v}$ significa deus. Posto isto, Heidegger (1957, p. 141-2) traduz o fragmento 119 da seguinte maneira: "Enquanto é um homem, o homem habita na proximidade do Deus". ${ }^{20} \mathrm{E}$ acrescenta que, por morada, devese ainda considerar o lugar onde costumeiramente o homem vive, vale dizer, $o$ espaço habitual de sua permanência [der geheure Aufenthalt]. Pois é ele que está aberto à presença do Deus, do Estranho e do Extraordinário (des Un-geheuren). No texto alemão, acentua-se o contraste entre o costumeiro e o habitual e o que é estranho e in-audito, através do jogo de palavras: "geheuer" e "Un-geheuer."21

\section{À guisa de uma conclusão}

$\mathrm{Na}$ Grécia arcaica, os homens viviam na vizinhança dos deuses. Conta Aristóteles que, certo dia, Heráclito de Éfeso, ao ver o espanto de alguns ilustres visitantes que vieram vê-lo e encontraram-no aquecendo-se junto ao forno de uma padaria, assim lhes falou:

\section{"Aqui também os deuses estão presentes."

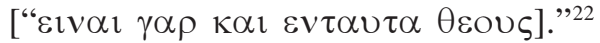

Com isto ele queria dizer que, no espaço aberto da vida simples e costumeira de todo dia, o homem grego vivia na vizinhança dos deuses.

Será que esta interpretação heideggeriana do sentido originário da palavra Lógos traduz o que é o Lógos heraclitiano? Para responder a esta pergunta, Heidegger procede a uma minuciosa análise do fragmento 50, e nos oferece, de um modo diferente, mas não menos enigmático do que o próprio fragmento de Heráclito, a seguinte leitura:

20. "Der Mensch wohnt, insofern er Mensch ist, in der Nähe des Gottes." Cf. Heidegger, M., 1957, p. 141-2.

21. Eis como Heidegger traduz e interpreta o Fragmento 119: "A morada costumeira [der (geheure) Aufenthalt] é, para o homem, a abertura para a presença do deus (o estranho) [das Offene für die Anwesung des Gottes (des Un-geheuren)].” Cf. Heidegger, M., 1957, p. 144-5.

22. Cf. Aristóteles. De partibus. Animalium. A 5, 645 a 17 - Citado por Heidegger, M., 1957, p. 140-1. 


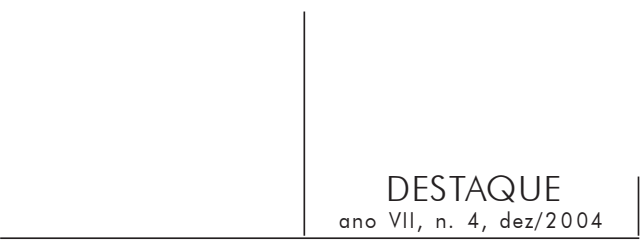

Não me escuteis a mim, o mortal que vos fala; mas sede atentos ao pousar que recolhe [ou seja, ao Lógos no seu sentido originário]; começai por pertencer-lhe, então ouvireis propriamente falar [porque só se ouve bem o Lógos, quando a ele se pertence]; um ouvir é, enquanto tiver lugar um deixar-estendidodiante-uma-coisa-junto-da-outra, diante do qual se estende o conjunto, o deixar-estendido que recolhe, o pousar que recolhe [O Lógos nomeia aquilo que reúne na presença. Nomeia a presença dos entes que se presentam no desvelamento]. Quando acontece que o deixar-estendido-diante deixa estendido, produz-se, então, alguma coisa de bem disposta [é sábio quem ouve o lógos e a ele pertence]; pois o bem disposto propriamente dito, o destino, somente é: únicouno que tudo unifica [O lógos é o destino que para tudo determina o lugar que é seu]. (Heidegger, 1973a, p. 127; o que se encontra entre colchetes são reflexões minhas).

Em nada esta leitura interpretativa é menos enigmática do que o Fragmento original de Heráclito. O próprio Heidegger o reconhece. Mas, nem por isso, é menos "esclarecedora". O clarão do relâmpago só ilumina na escuridão da noite. Nas Bacantes, Eurípides (1993) diz que, na obscuridade, existe algo de grandioso, porque "as trevas são sagradas" (p. 229). Ou, para dizê-lo com as palavras do próprio Heidegger: "é mais salutar caminhar no estranho do que instalar-se no óbvio".

\section{Referências}

Antoine de Saint-Exupéry. Le Petit Prince. In: Oeuvres. Paris: Gallimard, 1953.

Aristóteles. De Partibus animalium. In: The Basic Works of Aristotle. Edited and with an Introduction by Richard Mckeon. Randon House: New York, 194.

Carneiro Leão, Emmanuel e Wrublewski, Sérgio. Os pensadores originários: Anaximandro, Parmênides, Heráclito. Introdução e tradução. Petrópolis: Vozes, 1993.

Eurípides. As Bacantes. In: Efigênia em Aulis, As Fenícias, As Bacantes. Tradução do grego e apresentação de Mário da Gama Kuri. Rio de Janeiro: Jorge Zahar, 1933.

Diels, Hermann. Die Fragmente der Vorsokratiker. Howohlt Hamburg, 1957.

Frère, Jean. Les Grecs et le désir de l'Être. Des Préplatoniciens à Aristote. Paris: Les Belles Lettres, 1981.

HeIdegGer, Martin. Vorträge und Aufsatz. Pfulligen: Günther Neske, 1954.

Lettre sur l'Humanisme. Texte allemand traduit et présenté par Roger Munier. Paris: Aubier, Editions Montaigne, 1957.

Logos (Heráclito, Fragmento 50). Trad. Ernildo Stein. In: Os Pré-socráticos. São

Paulo: Abril Cultural, 1973a. p. 117-29. (Os Pensadores). 


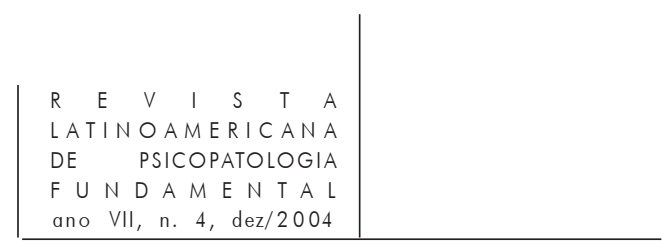

Alétheia (Heráclito, Fragmento 16). Trad. Ernildo Stein. In Os Pré-socráticos. São Paulo: Abril Cultural, 1973b. p. 129-142. (Os Pensadores). Introdução à metafísica. São Paulo: Tempo Brasileiro, 1987.

JAEGER, Werner. Early Christianity and Greek Paideia. Livro publicado em 1961 a partir das conferências pronunciadas pelo autor na Universidade de Havard em 1960. JEAniÈre, Abel. La pensée d'Héraclite d'Éphèse. Avec la traduction intégrale des fragments. Paris: Aubier, 1959.

Miranda, Maria do Carmo Tavares de. Martin Heidegger, filósofo do Ser. Revista Brasileira de Filosofia do Instituto Brasileiro de Filosofia, vol. XXVI, fasc. 103, jul.ago.set./1976.

Nietzsche, Friedrich. A filosofia na época da tragédia [\$ 5,6,7 e 8]. Trad. Rubens Rodrigues Torres Filho. In: Os Pré-socráticos. São Paulo: Abril Cultural, 1973. p. 10816. (Os Pensadores).

Pereira, Isidro. Dicionário Grego-Português - Português-Grego. Braga: Livraria. AI. s/d.

Ramnoux, Clémence. Héraclite ou l'homme entre les choses et les mots. Paris: Les Belles Lettres, 1959.

Rocci, Lorenzo. Vocabulário Greco-Italiano. 4 edizione. Roma, Napoli: Città Del Castello, 1949.

Rocна, Zeferino. O desejo na Grécia Arcaica. Revista Latinoamericana de Psicopatologia Fundamental, São Paulo, v. II, n. 4, p. 94-122, dez./1999.

Psyché. Os caminhos do acontecer psíquico na Grécia Antiga. Revista Latinoamericana de Psicopatologia Frundamental, São Paulo, v. IV, n. 2, p. 67-91, jun./2001.

SNELl, Bruno. Die Entdeckung des Geistes. Göttingen: Vandenbroeck \& Ruprecht, 1975. Trad. Portuguesa: A descoberta do espírito. Trad. Artur Mourão. Lisboa: Edições $70,1992$.

VAZ, Henrique C. de Lima. Sentido e não-sentido na crise da modernidade. Síntese, Nova fase, Belo Horizonte, v. 21, n. 64, p. 5-14, 1994.

\section{Resumos}

El artículo tiene como objetivo mostrar el papel esencial de Logos en la filosofía de Heráclito de Éfeso y es dividido en tres partes. En la primera, el autor presenta Heráclito como un pensador originario, llamado también de "obscuro". La segunda parte hace consideraciones sobre la etimología de la palabra logos, destacando su sentido originario (a la luz del comentario de Heidegger a los fragmentos 50 y 16 de 


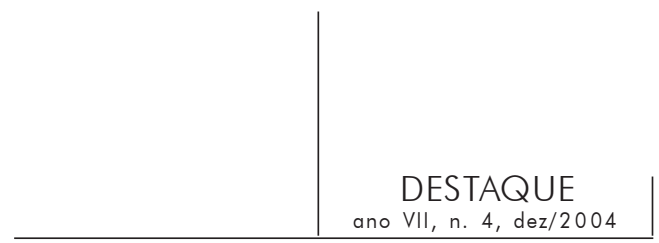

Heráclito sobre Logos y la Aletheia) y focaliza la importancia del sentido originario de Logos para pensar phynai da Phycis, como lo entendían los primeros filósofos griegos. La tercera parte muestra como Heráclito de Efeso, con la doctrina de Logos redimensionó la visión de la psyché humana que dominaba Grecia Arcaica.

Palabras claves: Heráclito de Éfeso, Logos, y Logos da psyché

Cet article a pour objectif de montrer le rôle essentiel du Logos dans la philosophie de Héraclite d'Ephèse et est divisé en trois parties. Dans la première partie, l'auteur présente Héraclite comme un penseur originaire, surnommé "l'obscure". La seconde partie apporte quelques considérations sur l'étymologie du mot Logos, et met en exergue son sens originaire, à la lumière du commentaire de Heidegger sur les Fragments 50 et 16 de Héraclite sur le Logos et la Alétheia, et se focalise sur l'importance du sens originaire de Logos pour penser le phynai de la Physis, tel que le comprenaient les premiers philosophes grecques. La troisième partie montre comment Héraclite d'Ephèse, avec la doctrine du Logos, a redimensionné la vision de la psyché humaine qui dominait la Grèce Antique.

Mots clés: Héraclite d'Ephèse, Logos et Logos de la psyché

This article, divided into three sections, explores the key role of Lógos in the philosophy of Heraclitus of Ephesus. Heraclitus, known by the epithet of "The Obscure" is presented in the first section as a fontal thinker. The second part focuses on the etymology of the word logos highlighting the word's original meaning in the light of Heidegger's comments in Fragments 50 and 16 about "Lógos" and "Alétheia." The second part focuses on the importance of the original meaning of Lógos in considerations on the phynai in Physis, as understood by Greek philosophers. The third section discusses how Heraclitus employs the doctrine of Lógos to redefine his view of the human psyche that was prevalent in Ancient Greece.

Key words: Heraclitus of Ephesus, Lógos and Lógos of the human psyche

Versão inicial recebida em outubro de 2004

Versão revisada recebida em novembro de 2004 